Higher Education, Nation Character, and Religious Moderation Program: A Public Policy Perspective
Journal of Asian Social Science Research 2021, Vol. 3, No. 1: 73-92 https://cassr.net/jassr/ (C) The Author(s) 2021

\title{
Tatang Sudrajat*
}

Universitas Sangga Buana, Bandung, Indonesia

\section{Supiana}

Universitas Islam Negeri Sunan Gunung Djati, Bandung, Indonesia

\section{Qiqi Yuliati Zakiah}

Universitas Islam Negeri Sunan Gunung Djati, Bandung, Indonesia

\begin{abstract}
The diversity of the Indonesian nation in terms of religion, ethnicity, race, local culture, and others is an inevitable reality. It constitutes the nation's socio-cultural capital, wealth, and potential to advance in which Indonesia can be proud of. But, it can also lead to attitudes and behaviour that damage national integration. Attitudes and behaviour that are tolerant of differences, inclusive, and moderate, especially in religious life, are the main pillars of a strong nation. Currently, the attitudes and behaviour of certain groups of citizens and individuals show the opposite and these dominate the Indonesian public sphere. Using normative juridical methods and literature, this article examines the religious moderation program launched by the Indonesian government under the coordination of the Ministry of Religious Affairs as an effort to deal with the rising religious intolerance and violence in Indonesia. From a public policy perspective, this article aims to analyse actors that are involved in the religious moderation program initiated by the Ministry of Religious Affairs. Higher education institutions with their resources have the opportunity to support this program. The religious moderation program is an implication of the policy environment that is currently embedded in people's daily lives.
\end{abstract}

\footnotetext{
* Corresponding author:

Tatang Sudrajat

Komp. Griya Bandung Asri 2, Blok H 4, No 10, Bojongsoang, Bandung, Indonesia.

Email: id.tatangsudrajat@gmail.com
} 


\section{Key Words}

Public policy, nation character, religious moderation, higher education

\section{Introduction}

The plurality of Indonesia, especially in religious life, has become a sociological reality for hundreds of years, which has been integrated into the ripples of daily life, long before the formation of Indonesia as a nationstate. The diversity of religions embraced by the citizens of the nation with their various dynamics has been transformed into an incomparable sociocultural wealth. Social differentiation in religious life has indeed become a gift from God because it forms one of the supporting factors for the rise of a sense of nationality to seize the independence that the colonizers took for more than three centuries. Diversity in religious beliefs was not a barrier for the founding fathers to knit the spirit of unity in forming a sovereign state.

After experiencing life as an independent nation for more than 75 years, it does not mean that the life of the nation is free from the potential threat of national disintegration. Intolerant attitudes and behaviour towards people with different religious beliefs and behaviour that absolutes the truth of personal religious views to others, even considering them as infidels, have emerged as phenomena that should be taken seriously. The superficial perspective and understanding of religion for some members of the community has turned into acts of terror wrapped in the argument of jihad in the name of religion.

Therefore, the religious moderation program initiated by the Ministry of Religious Affairs in 2017 is one concrete step in dealing with this problem. This is based on the Ministry of Religious Affairs' understanding and analysis of public problems in the form of threats to national unity due to selfish attitudes and behaviour and wanting to win for themselves in daily religious life. For the effectiveness of this program, it is beyond question that the Ministry of Religious Affairs cannot work alone. It is necessary to collaborate with various elements of society so that this religious moderation program can achieve its goals. One of them is higher education, whose implementation principles, according to Article 6, Letter c, Law Number 12 of 2012 concerning Higher Education, are democracy, fairness, and non-discriminatory with reverence for human rights, religious values, cultural values, pluralism, unity, and national unity.

This study aims to discuss the character of the nation, the role of universities, and religious moderation programs from a public policy 
perspective. The theoretical framework or concept used relates to the components of public policy, categories of public policy, and public policy systems.

This study uses qualitative methods and literature study. Data were collected by interviewing several university leaders and lecturers who supported Religious Education, Pancasila Education, and Citizenship Education at several universities, public and private, in Bandung City and outside Bandung City. In addition, a literature review was also conducted by reviewing books and journal articles related to the research question. An analysis of documents in the form of laws and regulations and other texts related to religious moderation and higher education was also carried out.

\section{Nation Character}

Academic discussion about the national character is not something that has just emerged in the last twenty years, because President Sukarno has previously called it nation character building. The discussion of the character of the nation will not be separated from the discussion of values and morals in human life in individuals and groups. The content of good character according to Lickona (2016:15-16) is kindness. Virtues such as honesty, courage, justice, and compassion are a disposition to behave morally correct. Character is good objectivity of human qualities, whether known to humans or not. These virtues are affirmed by societies and religions around the world. According to Lickona (1992:51), character consists of operative values or values in action. A character has three interrelated parts: moral knowing, moral feeling, and moral behaviour. Good character consists of knowing the good, desiring the good, and doing the good habits of the mind, habits of the heart, and habits of action.

Goodness according to Lickona (2016:16) is objective good-not a subjective preference like taste in music or clothing-because goodness meets certain criteria: goodness determines what it means to be human, virtues increase the happiness and well-being of an individual, and they serve the common good and enable us to live and work in society. It is further stated that there are 10 essences of the most important virtues to build a strong character, namely wisdom, justice, fortitude, self-control, love, positive attitude, hard work, integrity, gratitude, and humility (Lickona 2016:16-20).

According to Ma'arif (2018:38), a character is human conduct, moral, temperament, or personality that is more inclined towards positivity although, in essence, human temperament or morals can also be bad or disagreeable. Character involves not only the physically visible body, but 
also the psychology, feelings, and the heart so it can become a character that tends and leans toward goodness. The character can only be formed through continuous education.

National character is one of the nine elements of the intangible power of a nation. As one of the national strengths, the national character must be maintained and constantly revitalized so that it can always be an inspiration and an encouragement and be able to function as the human capital of the nation because it determines the resilience of the nation (Anwar and Salim 2019:236). It is important to pay greater attention to the character of the nation, especially when we relate it to the current sociological facts that are full of hate speech, hoaxes, and narratives of hostility. The phenomenon of hoaxes, according to Hidayat (2019:258), seem to be growing more acute and have plagued our society, as with the spread of pornography or drugs. People become addicted to consuming and doing things that are considered fun but actually, harmful to themselves and society.

The character of the Indonesian nation is an accumulation of the character of each individual, which is an ideal context as set out in Pancasila as a source of value, will relate to five essential values, the first of which is the spiritual or religious value (i.e., belief in God). According to Kaelan (2010:80-81), value is essentially the nature or quality attached to an object as opposed to the object itself. Something containing value means that there are characteristics or qualities attached to that thing. A value contains ideals, hopes, and desires. Talking about values means talking about das sollen, not das sein; we enter the spiritual field of normative meaning, not cognitive, and the ideal world, not the real world. Notonegoro (in Kaelan 2010:82) classifies values into material values, vital values, and spiritual values. The last type of the three, spiritual values, consists of the value of truth, the value of beauty, the value of goodness or morals, and religious values. Pancasila values are classified as spiritual values. However, spiritual values recognize the existence of material and vital values.

The discussion about character and character education is also related to the conception of morals. Moral, according to Suseno (1987:19), refers to the good and bad of humans as humans. The moral field is the field of human life in terms of goodness as a human being. Moral norms are benchmarks for determining the right and wrong of human attitudes and actions in terms of good and bad as humans and not as actors in certain and limited roles. Morality, according to Sulismadi and Sofwani (2011:69), is a source of unwritten rules that people hold fast because they have good values according to the size of the values that develop in society. 
Concerning other identities that pose a threat to national "identity", according to Bartolomeus Samho, one of the strategic efforts to overcome them is the existence of a systematic movement toward internalizing Pancasila values in the education sector without using Pancasila as an instrument of political interest. The implementation of Pancasila education should always be oriented, among others, to building the character of the nation's generation toward values such as obedience to the rules, devotion to God, honesty, justice, peace, happiness, freedom, simplicity, respect, discipline, tolerance, a sense of unity, cooperation, responsibility, love for the homeland, love, and love for the environment (Bolo et al. 2012:269).

\section{Religious Moderation Program}

The religious moderation program is closely related to the policymakers' in-depth analysis of social facts in recent years as well as various acts of violence with religious nuances before the collapse of the New Order regime. In Azra's view, various forms of violence in the past were "political and economic radicalism" that used or manipulated religious symbols; the misuse and abuse of religious symbols are still rampant in political and economic violence scenes (Azra 2000:11).

Indonesian society is very diverse. One aspect of social differentiation is religion, in which case, if selfishness emerges from the majority group, especially if it coincides with political power, it can potentially lead to social disharmony. Therefore, tolerance, which is essentially an attitude and behaviour that respects differences, has a very essential role. Tolerance, according to Suseno (2000:108), is not only a pragmatic demand for the sake of peaceful coexistence but also a moral and religious requirement. The full belief of religious adherents, including adherents of Islam, regarding the truth of their religion as well as the errors of other models, does not have to be highlighted, let alone echoed, in a pluralistic society (Shihab 2018:49).

Within the last two decades, facts show that the public sphere is filled with the behaviour of some groups of individuals who always feel they are the most correct parties in understanding religion. Quantitatively, they are not groups in the majority position, but because of the influence of social media and the dominance of the silent majority so far, their actions are getting on stage. According to Akhmadi (2019:49), in the multicultural Indonesian society, an exclusive religious attitude that only recognizes truth and salvation unilaterally can certainly cause friction between religious groups. In the context of religious fundamentalism, to avoid disharmony, it 
is necessary to cultivate a moderate religious way, or an inclusive way of Islam or an open religious attitude, which is called an attitude of religious moderation. Thus, religious moderation is a middle way amid religious diversity in Indonesia. Moderation is an archipelago culture that goes hand in hand and does not cause religions and local wisdom to negate each other. It is not causing a contradiction between each other but seeking a tolerant solution.

Moderation or wasathiyyah is not an attitude that is not clear or unequivocal toward something like a passive neutral attitude, nor is it a mathematical middle ground as understood by some proponents of the thoughts of Greek philosophers (Shihab 2020:xi). Wasathiyyah which characterizes Islamic teachings is the balance between spirit and body, the world and the hereafter, religion and state, individual and society, ideas and reality, old and new, reason and naql (religious texts), religion and science, modernity and tradition, and so on. It is not a recipe for which details are available but a continuous effort to find and apply it (Shihab 2020:43-44). Religion moderation is different from religious moderation. Religion does not need to be moderated because religion itself teaches the principles of moderation, justice, and balance. It is not religion that must be moderated, but the way religious adherents carry out their religious teachings (Ministry of Religious Affairs 2019:15). In this regard, consistency, sincerity, and optimism are needed to continue to inflame moderate character in religious behaviour in people's daily lives.

The current struggle of the nation for the realization of a just and prosperous society requires the presence of a harmonious and peaceful social order. According to Hidayat (2019:290), the motto Bhinneka Tunggal $I k a$ and the agreement of Pancasila as a guideline for the life of the nation and state are historical evidence and political promises so that Indonesia is not controlled and owned by primordial, communal, and tribal ideologies because, if that happens, Indonesia will surely be noisy, lose its spirit, and deny being itself at very expensive social, economic, and political costs. It was further stated that fierce religious expressions would grow in prominence and become less enlightening to jointly advance and prosper the Indonesian people (Hidayat 2019:293). The government must be firm and continue to strive for the presence of a moderate religious atmosphere to achieve national ideals as formulated by the founding fathers in the Preamble to the 1945 Constitution.

The national character that is expected through the religious moderation program is inseparable from the national development program. In this regard, one of the missions formulated to realize the vision of national development for 2005-2025 as stated in Law Number 17 of 2007 is to 
create a society with noble character, morality, ethics, culture, and civility based on the Pancasila philosophy. This includes strengthening the identity and character of the nation through education that aims to form people who are devoted to God Almighty.

The program's targets include the realization of a strong, competitive, noble, and moral character based on the Pancasila philosophy which is characterized by the character and behaviour of Indonesian people and people who believe and fear God Almighty, have virtue and tolerance, work together, demonstrate a patriotic spirit, develop dynamically, and go science and technology-oriented. The long-term development direction for 2005-2025 is that the development and strengthening of national identity are aimed at realizing the national character and social system that is rooted, unique, modern, and superior. The development of national identity is carried out through transformation, revitalization, and re-actualisation of the nation's cultural values that have superior potential as well as through the application of constructive modern values.

\section{The Role of Universities}

Regarding the issue of national character and the importance of tolerance and religious moderation programs, according to Howlett and Ramesh (1995:51), universities play the role as public policy institutions. According to them, policy institutions are structures and organizations of the state, society, and the international system (1995:51). Concerning the development of society, nation, and culture, higher education is the centre for the growth and development of national civilization. A civilized nation is indicated by citizens with character.

In this regard, one of the functions of higher education, according to Article 4 of Law Number 12 of 2012, is to develop capabilities and shape the character and civilization of a dignified nation to educate the nation's life. Students are the elements of the higher education community that can play a role in supporting this program. Therefore, it makes sense when it is stated that one of the goals of higher education as referred to in Article 5 is the development of the potential of students to become human beings who believe in and fear God Almighty and are noble, healthy, knowledgeable, capable, creative, independent, skilled, competent, and cultured for the benefit of the nation.

The obligations of higher education institutions are known as the Tridharma of Higher Education, consisting of Education, Research, and Community Service, as referred to in Law Number 12 of 2012. There is a 
national policy as referred to in Article 35 paragraph (4) which stipulates four subjects as general compulsory subjects nationally, including Religious Education, Pancasila Education, and Citizenship Education. The religious moderation program is related to the existence of these three courses. With their organizational resources, universities have a great opportunity to support this program.

According to Tilaar (1997:167), one of the characteristics that indicate that universities are "partners in progress", which means that universities must create quality graduates. Among other things, universities have given birth to independent and responsible scientists. These scientists are independent in thinking and innovative in commitment to building society as a whole (Tilaar 1997:167). The responsibilities of these college graduates include, among many things, taking a real role in everyday life in a pluralistic society.

The challenges faced by universities are getting bigger along with the problems faced by the nation, especially in preparing quality human beings. From time to time, the challenges and problems faced by the Indonesian nation and state are getting bigger and more complex along with the increasingly globalized human life. According to Najmina (2021:53), complex problems require a solution and real action. A commendable national character, excellent citizen intelligence, strong Indonesian nationalism, the ability to live in a multicultural society, and culture need to be the focus of the personal development of every citizen of the nation (Najmina 2012:53).

The role of universities is at stake to provide effective solutions to the nation's concrete problems regarding the issue of diversity. Universities, following the authority they have as stated in Article 58 of Law Number 12 of 2012, have functions and roles including being places for student and community learning and centres for the development of national civilization. With the various organizational resources they have, universities administer the learning of Religious Education, Pancasila Education, and Citizenship Education not only through curricular activities but also through cocurricular and extra-curricular activities. Higher education is not an ivory tower that is far from the affairs and problems of the nation but a tower of fire that with its light can illuminate the surrounding space with solutions to these problems.

In the Religious Education course, the assigned lecturers have a great responsibility to ensure that students become adherents of a moderate religion amidst the diversity of religions and beliefs held. According to Arifin (2019:75), one of the important and strategic social institutions to 
instil a more sympathetic and empathetic construct for the existence of other religions is education. It is time for educational institutions to be used as nurseries to foster an egalitarian attitude toward the existence of other religions. Religious learning with plural and multicultural pattern can be understood as a process of awareness of the existence of religious diversity and the willingness to apply every religion in an egalitarian manner (Arifin 2019:75). Currently, universities seem to be in a race against time due to the ideological infiltration of campus residents, especially students, so if this is left campuses may become perfect nurseries for the seeds of intolerance, radicalism, and terrorism.

In the Pancasila Education course, through the implementation of the values of unity and humanity from the national ideology of Pancasila, lecturers can convince students that moderate attitudes and behaviour in religion are a big share for national integration. If this has been internalized in their daily attitudes and behaviour, it will contribute greatly to the realization of the nation's character. Related to this, Bartholomew Samho (cited in Bolo et al. 2012:270) states that one of the orientations of implementing Pancasila education is building the character of the nation's generation toward values such as obedience to rules, devotion to God, honesty, justice, peace, happiness, freedom, simplicity, respect, discipline, tolerance, a sense of unity, cooperation, responsibility, love for the homeland, love, and love for the environment.

There must be full awareness from university leaders and lecturers who support Pancasila that exclusive and intolerant behaviour in religious life will become the forerunner of social disharmony, which in turn will lead to national disintegration. This is related to the main objective of studying Pancasila in universities, as stated by Sylvester Kanisius Laku (cited in Bolo et al. 2012:35-36), to invite students to critically study Pancasila, both as a moral-juridical discourse and as a humanistic discourse, invite students to understand the dimensions of knowledge in Pancasila, and invite students to reflect critically Pancasila concerning living together as a nation.

Through the subject of the rights and obligations of citizens in the Citizenship Education course, lecturers can conduct intellectual exercises regarding the importance of religious moderation as a tangible manifestation of the obligation to respect religious diversity in society. Moderate religion, according to Nurdin and Naqqiyah (2019:94), has become a characteristic of religious people in Indonesia, and basically, it is more suitable to be applied to the pluralistic culture of Indonesian society. Respectful and tolerant attitudes and behaviour amid differences 
are prerequisites for the realization of social harmony so that religious moderation programs are seen as the right solution. This is in line with what is stated by Quraish Shihab (cited in Fahri and Zainuri 2019:97) that moderation contains several pillars, including justice, balance, and tolerance. Religious moderation is the key to the realization of tolerance and harmony, be it at the local, national, or global levels (Kementerian Agama 2019:18).

In this regard, it requires a high commitment from the leaders of universities as policy actors to place these three courses fairly and proportionally as the treatment of other courses. The seriousness of this commitment will be seen in the assignments of lecturers to teach this course because it will be related to the sustainability of social harmony in the life of the nation. Prudence and careful selectivity are needed to obtain adequate lecturer figures in terms of academic capability and personal integrity.

\section{Public Policy Component}

From the perspective of public policy, the religious moderation program is part of the policy in the field of religious affairs. One way to further identify the program, a policy analyst can analyze it from what Gerston (2010:7) puts forward as components of public policy, namely issues, actors, resources, institutions, and the level of government. He states that public policy is the combination of basic decisions, commitments, and actions made by those who hold or influence government positions of authority. Furthermore, he mentions five components of the policy as follows: issues that appear on the public agenda; actors who present, interpret, and respond to those issues; resources affected by those issues; institutions that deal with those issues; and the levels of government that addresses those issues (Gerston 2010:8).

Thus, the aspects studied will relate to certain issues, public problems, or policy issues that are controversial. The actors in the community and government circles who are involved have an interest and a stake in the formulation and determination of policies. The resources of government organizations that are prepared and deployed, both human and non-human, are also the focus of a policy analyst's study. Another component that a policy analyst can examine relates to the level of government at which a policy is set.

National character, intolerance, exclusivity, and radicalism in religious views as well as religious moderation, are examples of the component of 
public policy called issues. Regarding issues, Gerston (2010:8) mentions that although policy areas include a range of ever-changing public needs, the types of issues can be divided into two broad categories: substantive and symbolic. If policy problems are whole systems of problems, it follows that policy issues must be equally complex. Policy issues not only involve disagreements about actual or potential courses of action; they also reflect competing views of the nature of problems themselves (Dunn 1981:101).

The unit that organizes higher education is the university. The chancellor as the head of the university and lecturers as educators and scientists who are directly related to the support for the religious moderation program are among policy actors. According to Howlett and Ramesh (1995:51), the term "actors" includes both state and societal actors, some of whom are intimately involved in the policy process while others are only marginally so. Actors in the policy process may be either individuals or groups. Policy actors may be divided into the following five categories: elected officials, appointed officials, interest groups, research organizations, and mass media (Howlett and Ramesh 1995:52).

The ranks of universities, public and private, which can generally be grouped into appointed officials, research organizations, and interest groups, can be used by the government to stem the threat of radicalism and terrorism. In the view of Parawansa (2013:97-98), the involvement of civil society and the intensity of dialogue are very important to eradicate the roots of terrorism, especially due to the radicalization of religious understanding. One aspect that must be considered is ideological because the root of terrorism is a wrong understanding of ideology.

This moderation program involves various organizational resources, both human and non-human. Human resources consist of state civil apparatus in the Ministry of Religious Affairs following the duties and authorities stipulated in the organizational structure and work procedures. Meanwhile, non-human resources include the finances, facilities, and information owned by the Ministry of Religious Affairs. Apart from those in the Ministry of Religious Affairs, there are other parties involved, with various organizational resources, from the initial planning to the issuance of the decision on this program.

As an integral part of the government structure, the Ministry of Religious Affairs has a network of organizations down to the sub-district level. This is a very important component of public policy because it relates to the authority and legality of a government program. This level of government is related to the existence of public policy institutions. Public 
institutions, according to Gerston (2019:345), are the vehicles through which public policies are formulated and carried out. The institution rings of formality and organization, but it also suggests the routes for traffic travelling through the policy process (2010:11). This aspect relates to various institutions that are expected to assist in the effective implementation of this program, one of which is an educational institution. According to Sutrisno (2019:345), one way to actualize the concept of religious moderation in the context of a multicultural society is to make educational institutions a laboratory basis for religious moderation.

From the aspect of government authority, this religious moderation program is part of government affairs as referred to in Article 10, paragraph (1), letter f of Law Number 23 of 2014 concerning Regional Government, namely religion. This matter is one of the six absolute government affairs, which are fully under the authority of the central government, as regulated in Article 9, paragraph 2. The legality of a public policy or program that is set and implemented by the government is certainly related to legitimacy. Dye (1978:4) argues that one of the consequences of the institutional model of public policy is legitimacy. In this regard, he states that government lends legitimacy to policies. Governmental policies are generally regarded as legal obligations which command the loyalty of citizens. People may regard the policies of other groups and associations in society-corporations, among others, as important and even binding. But only government policies involve legal obligations (Dye1987:21). This is also in line with what Anderson states that in their positive form, they are based on law and are authoritative (Dye 1978:4).

\section{Public Policy Category}

To understand public policy, one should examine what Anderson calls "the category of public policy". He states that the nature of public policy as a course of action can be better understood if it is broken down into several categories, namely policy demands, decisions, statements, output, and outcomes (Anderson 1978:3-5).

Intolerant, radical, exclusive, and extreme attitudes and behaviour in religious life by certain groups are public issues that in the last 20 years have often appeared in public spaces and greatly disturbed other community groups. It is not surprising that there are reactions from various groups who oppose this behaviour which is voiced to the government as the holder of state authority. This is a policy category that Anderson calls "policy demand". This category refers to demands or claims made upon public 
officials by the actors, private or official, in the political system for action or action on some perceived problem (Anderson 1978:4).

The establishment of a religious moderation program by the Minister of Religious Affairs as the top policymaker at the Ministry of Religious Affairs in 2017 is a form of policy decision. Currently, the Ministry of Religious Affairs is preparing a draft Regulation of the Minister of Religion regarding this religious moderation program to give it greater juridical strength for its operation. According to Anderson (1978:4), decisions are made by public officials that authorize or give direction and content to public policy actions including decisions to enact statutes, issue executive orders or edicts, promulgate administrative rules, or make important judicial interpretations of the law.

The existence of a policy decision is a product of the legitimacy of public policy, which is a series of decisions made by a person, a group of policy actors, or an institution. According to Anderson (1978:14), several values influence the decision-making process. He states that most of the values that may serve to guide the behaviour of decision-makers may be summarized in four categories. According to him, the behaviour of actors or public policy institutions as decision-makers can be grouped into five types as follow: are political values, organization values, personal values, policy values, and ideological values (Anderson 1978:14).

Policy statements, among others, appear in the form of various official statements from the Minister of Religious Affairs or officials of the Ministry of Religious Affairs $\mathrm{n}$ various forums about the importance of religious moderation programs. According to Anderson (1978:5), these policy statements are the formal expression or articulation of public policy. Included are legislative statutes, executive orders and decrees, administrative rules and regulations, and court opinions, as well as statements and speeches by public officials in dictating the intentions and goals of the government and what will be done to realize them. At the moment, efforts are being made to issue a stipulation in the form of a Presidential Regulation on this religious moderation program.

The implementation of the religious moderation program includes the involvement of various social institutions in helping to encourage the realization of a moderate religious life, which is a form of policy output. According to Anderson (1978:5), this policy output is the "tangible manifestation" of public policies, the things done in pursuance of policy decisions and statements. Policy output is what a government does, as distinguished from what it says it is going to do (Anderson 1978:5). 
Another form can also be the number of universities as policy stakeholders that make internal agendas for members of their academic communities as a continuation of the religious moderation program.

The realization of a moderate religious life in daily life, which can be seen from the attitudes and behaviour of community members in their social interactions, is a manifestation of policy outcome. According to Anderson (1978:5), policy outcomes are the consequences for society, intended or unintended, that flow from action or inaction by the government. Of course, the consequences for the community in question are something that is in line with expectations as designed by policymakers. One condition which is the antithesis of what Latif (2018:10-11) describes as the spread of religious violence which is an explosion of the tendency to understand, appreciate, and practice divinity that is not cultured does not spark the spirit of rahmatan lil alamin (love for all the worlds). Distortions in the practice of the precepts of divinity are exacerbated by distortions in the practice of the precepts of unity.

\section{The Policy System}

The religious moderation program from the Ministry of Religious Affairs for the presence of a harmonious and peaceful atmosphere of religious life is a form of public policy. The term "program" in the realm of policy studies is something that is attached to other terminology in the study of public policy. Jones (1984:25) explains that the word "policy" is often used interchangeably with goals, programs, decisions, laws, standards, proposals, and grand designs. In other words, referring to Jones's opinion, the religious moderation program is one form of public policy because it is a real state/government's response to arising public problems and it contains the content of public interest.

The birth of this program is not a single phenomenon, but a result of various political processes, both those that take place in the political infrastructure and those that take place in the political superstructure. Meanwhile, the condition of commotion in the public sphere regarding intolerant attitudes and behaviour, feeling the most correct in religious beliefs while stating that others are wrong, radical views on religious teachings, disbelief in other people of the same religion, politicization of religion in elections, the intention of the establishment of an Islamic state, and even acts of terror in the name of religion can be seen as a policy environment. 
According to Dunn (1981:47), the policy environment is the specific context in which events surrounding a policy issue occur, which influences and is in turn influenced by policy stakeholders and public policies. In this regard, Anderson (1978:27) argues that demands for policy actions are generated in the environment and transmitted to the political system; at the same time, the environment places limits and constraints upon what can be done by policymakers. Anderson (1978:27) also mentions that there are three types of the policy environment, namely geographical characteristics, political culture, and socioeconomic variables.

Dye (1987:6) calls this policy environment a society in the form of social and economic conditions, which consist of wealth, urbanization, economic system, education levels, class structure, racial composition, and religious make-up. Within the framework of the policy system, the policy environment greatly determines the existence and success of a public policy or program when it is implemented. This is because this environment can act as a variable or factor that influences (independent variable) the publication of a public policy, or it can also be in the position of an affected variable (dependent variable).

This policy environment together with policy stakeholders and public policy in the form of a religious moderation program are the three elements of what Dunn calls "the Policy System". He states that the Policy System is an overall institutional pattern within which policies are made, which has three elements, namely public policy, policy environment, and policy stakeholders (1981:46). The process of establishing a religious moderation program involves many actors and policy institutions which, according to Dunn's opinion, are part of the Policy Stakeholders. These policy stakeholders are individuals or groups that have a stake in policies because they affect and are affected by governmental decisions (1981:47).

Public policy, including public policy in the religious field, is not a single phenomenon that exists in a vacuum. Various state or government regulations on religious affairs involve many actors and institutions as policy stakeholders according to the level of government. The issuance of the religious moderation program which then has the power of legality in the form of legislation is a tangible manifestation of the state/government's response to the demands of a policy environment that requires a cool and harmonious religious life in a pluralistic society.

When this religious moderation program has been established through a Ministerial Regulation or even through a Presidential Regulation, then as policy content this program will have an authoritative juridical basis 
in the implementation phase. As a first step, the Religious Moderation Working Group under the Ministry of Religious Affairs as well as other forms of activity are established as a form of seriousness for the presence of a cool religious life within the framework of nationality. Another strategic issue is the inclusion of religious moderation in the 2020-2024 National Medium-Term Development Plan (RPJMN) in accordance with Presidential Regulation Number 18 of 2020. In the context of public policy, another important step is the issuance of a Circular Letter of the DirectorGeneral of Islamic Education Number B-3663.1/ Dj.1/BA.02/10/2019 dated October 29, 2019, for the chancellors of State Islamic Universities to establish and organize the House of Religious Moderation. This is a space for nursing, educating, mentoring, and strengthening the religious moderation movement in the campus environment.

In other words, the religious moderation program as a public policy contains interdependence between the actors involved in the formulation and determination of the moderation program as policy stakeholders and the policy environment. This will be especially apparent when the program is implemented and has an impact on policy objectives. Schematically, by adapting Dunn's Policy System, this interdependence can be described in Graph 1.

\section{Graph 1}

Policy System

Source: Adaptation from Dunn (1981:47)

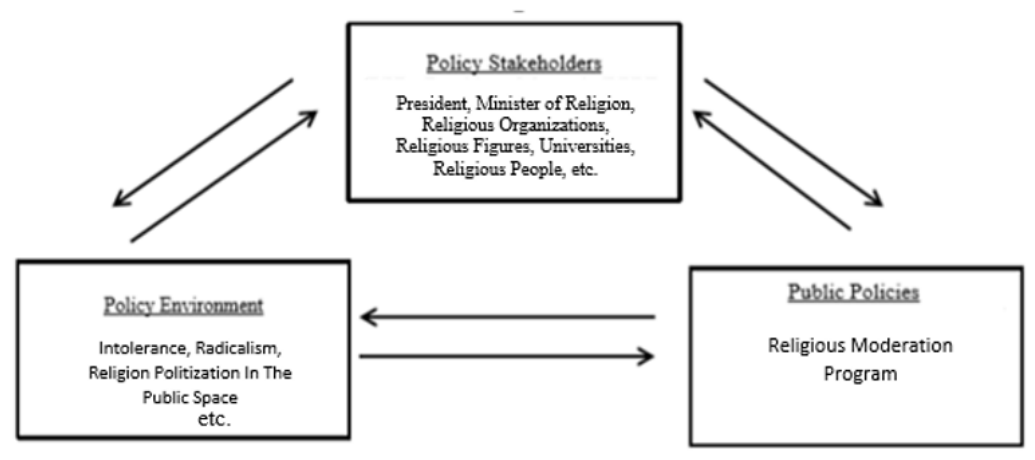




\section{Conclusion}

This article has shown that the character of the nation is very important to support the existence of the state and the sustainability of the government's efforts to implement national development programs. This is also related to the diverse socio-cultural characteristics. Various forms of attitudes and behaviour of some citizens who are intolerant, exclusive, and noisy with religious issues in the public sphere are a threat to social harmony and national integration. It argues that the religious moderation program initiated by the Ministry of Religious Affairs is the state's response to putting the public interest first. This program is a tangible form of public policy whose implementation requires the support of various parties, including universities. The activities of the Tridharma of Higher Education, especially the learning of Religious Education, Pancasila Education, and Citizenship Education, contribute to the support of the program.

\section{References}

Anderson, James E. 1978. Public Policy Making. Second Edition. New York: Holt, Rinehart and Winston.

Anwar, Syaiful and Agus Salim. 2019. "Pendidikan Islam dalam

Membangun Karakter Bangsa di Era Milenial”. .Al-Tadzkiyyah:

Jurnal Pendidikan Islam 9 (2):233-147.

Akhmadi, Agus. 2019. "Moderasi Beragama dalam Keragaman Indonesia”. Jurnal Diklat Keagamaan 13 (2):45-55.

Arifin, Syamsul. 2019. Populisme, Demokratisasi, Multikulturalisme: Artikulasi Baru Islam di Indonesia Dalam Nalar Agama Publik. Malang: Intrans Publishing.

Azra, Azyumardi. 2000. Menuju Masyarakat Madani. Gagasan, Fakta dan Tantangan. Bandung: Remaja Rosdakarya.

Bolo, Andreas Doweng dkk. 2012. Pancasila: Kekuatan Pembebas. Yogyakarta: Penerbit Kanisius.

Dunn, William N. 1981. Public Policy Analysis: An Introduction. Prentice Hall Inc. Englewood Cliffs.

Dye, Thomas R. 1987. Understanding Public Policy. Six Edition. New Jersey: Prentice Hall Inc. Angelwood Clifts.

Fahri, Mohamad and Ahmad Zainuri. 2019. "Moderasi Beragama di Indonesia". Intizar 25(2): 95-100.

Gerston, Larry N. 2010. Public Policy Making. Process and Principles. Third Edition. Armonk New York: M.E. Sharpe. 
Hidayat, Komaruddin. 2019. Agama Untuk Peradaban. Membumikan Etos Agama dalam Kehidupan. Tangerang Selatan : PT Pustaka Alvabet.

Howlett, Michael and M. Ramesh. 1995. Studying Public Policy: Policy Cycles and Policy Subsystems. New York: Oxford University Press.

Jones, Charles O. 1984. An Introduction to the Study of Public Policy. Third Edition. Monterey California: Brooks/Cole Publishing Company.

Kaelan. 2010. Pendidikan Pancasila. Yogyakarta: Penerbit Paradigma.

Kementerian Agama. 2019. Moderasi Beragama. Jakarta: Balitbang dan Diklat Kementerian Agama RI.

Kementerian Agama. 2019. Tanya Jawab Moderasi Beragama. Jakarta: Balitbang dan Diklat Kementerian Agama RI.

Latif, Yudi. 2018. Wawasan Pancasila: Bintang Penuntun untuk Pembudayaan. Jakarta: Mizan.

Lickona, Thomas. 1992. Educating for Character: How Our Schools Can Teach Respect and Responsibility. New York: Bantam Books.

Lickona, Thomas. 2016. Character Matters. Persoalan Karakter: Bagaimana Membantu Anak Mengembangkan Penilaian yang Baik, Integritas, dan Kebajikan Penting Lainnya. Terjemahan oleh Juma Abdu Wamaungo dan Jean Antunes Rudolf Zien. Jakarta : PT Bumi Aksara

Ma'arif, Muhammad Anas. 2018. “Analisis Strategi Pendidikan Karakter Melalui Hukuman Preventif”. Jurnal Pendidikan Islam.Ta'allum 6 (1):31-56.

Nurdin, Ali dan Maulidatus Syahrotin Naqqiyah. 2019. "Model Moderasi Beragama Berbasis Pesantren Salaf". Islamica: Jurnal Studi Keislaman 14 (1):82-102.

Najmina, Nana. 2012. "Pendidikan Multikultural Dalam Membentuk Karakter Bangsa Indonesia". Jupiis: Jurnal Pendidikan Ilmu-Ilmu Sosial 10 (1):52-56.

Parawansa, Khofifah Indar. 2013. Islam, NU dan Keindonesiaan. Bandung : Nuansa Cendekia.

Shihab, M. Quraish. 2018. Islam yang Saya Anut: Dasar-dasar Ajaran Islam. Tangerang Selatan: Lentera Hati.

Shihab M. Quraish. 2020. Wasathiyyah: Wawasan Islam tentang Moderasi Beragama. Tangerang Selatan: Lentera Hati 
Suseno, Franz Magnis. 1987. Etika Dasar: Masalah-masalah Pokok Filsafat Moral. Jakarta: Kanisius.

Suseno, Frans Magnis. 2000. Kuasa dan Moral. Jakarta: Gramedia Pustaka Utama.

Sutrisno, Edy. 2019. "Aktualisasi Moderasi Beragama di Lembaga Pendidikan”. Jurnal Bimas Islam 12 (1):323-348.

Tilaar, H.A.R. 1997. Pengembangan Sumber Daya Manusia dalam Era Globalisasi. Jakarta: Rasindo. 
